the arrival of the unusual sunsets last year, and that it has never been seen here before, at any rate within the last twenty years. This impression is founded, first, on the fact that, like Mr. Backhouse, I have been in the habit of frequently looking at solar halos for years past. Secondly, I have been engaged since September 8 last year in a series of observations with anemometers attached to a kite-string (latterly wire), which has naturally necessitated my frcquently looking up at the slcy. I remember noticing the halo in November, and calling the attention of my assistant to the beautiful salmon colour it showed in the interstices of a mackerel sky, which shut off the direct glare of the sun.

On scveral occasions I measured its radius with a theodolite I was using, and in every case the valuc came out either $22 \frac{1}{2}^{\circ}$ or 23. It must therefore be due, like the ordinary ice-halo, to refraction through hexagonal prisms. I noticed it all the way going out to America in August last, and saw it beautifully when standing on the Terrapin Bridge over Niagara Falls on August 23. A large black cloud had shut off the sun's glare, and the red border happened just to coincide with the edge of the cloud. I called the attention of some American ladies to the spectacle, which they had of course never noticed before, and which they admired immensely. I regard the sunset glows as partly an intensification of the halo, produced by the greater thickness of the stratum through which the refraction takes place when the sun is below the horizon (the sunset, in fact, being formed of the upper half of the halo which lingers behind) plus reflection from the same stratum, which can of course only come into operation when the sun shines obliquely on it. The fact of the halo remaining constant while the sunset glows have become weaker may be readily explained on the hypothesis that the stratum has gradually sunk to a lower level than it had last winter, since the duration and even brilliancy of the glow must of course vary directly with its height, whereas the halo at midday need not be sensibly altered by a variation in its level.

Three weeks ago yesterday, I saw the sun rise from the summit of Mount Washington, 6293 feet above sea-level, and at ten minutes to five o'clock saw, in addition to the usual sunrise effects, a large circle of rosy purplc haze situated about $15^{\circ}$ above the horizon, and apparently having no connection with the yellow and red horizontal bands beneath it. The morning was exquisitely fine, the only clouds being a few light streaky cirrostrati, as shown in diagram, and the air was as clear as it only can be in America. I may add that the haze circle appeared almost suddenly after the first yellowish light had been visible for twenty minutes, and as soon as the sun rose above the horizon it seemed to vanish almost entirely. I have seen the sun rise from various altitudes up to 12,000 feet, but I never saw anything so curious as this sunrise before. In fact, I went up mainly to see it, and was not disappointed.

Tunbridge Wells, September 27

$$
\text { E. DOUglas Archibald }
$$

\section{Cole's Pits}

YOUR note on the result of Gen. Pitt-Rivers' examination of the Pen Pits (Somerset) in this week's number of NATURE (p. 545) reminds me of a serics of similar pits in this county of Berks, known as "Cole's Pits." They are situated near the branch of the Great Western Railway which runs from Uppington to Faringdon. I have visited them more than once when on visits to Wadley, the residence of my friend Mr. T. L. Goodlake, 1.P. They correspond generally with the description given in NATURE of the Pen Pits, are probably of quite equal extent, are similarly situated on rising ground forming the cap of a ridge of hills, and are on the same Greensand formation. Many and various theories have been propounded from time to time by antiquarians, and of course the name by which these pits have been known for generations has been appealed to as connecting them with the "merry King Cole," ard giving support to the views of those who regard them as traces of an "ancient British town." The utter absence of order in the arrangement of these shallow holes and rude mounds (for they are notbing more) excited my suspicion, nor could I see much in them to suggest occupation by any race which has inhabited these islands even so late as the time of the ancient Britons. On further investigation of them I came across a more modern $\mathrm{s}$ )rt of hut, consisting of a space rudely roofed over, the back of which was cut into the side of one of these grass-grown banks. The idea occurred to me that this would help to furnish evidence, since, if these hollows were dug in the strata of the hill to be roofed over for human habitation (the notion which, I am told, finds general favour) we ought to find some traces of stratificalion in a section thus presented to us. Not a trace of this was to be found; the section showed nothing but a chaotic mass of rubbly material with no more order in its arrangement than is to be found in the waste heaps of any old quarry or in a terminal moraine.

So far one's first impressions of the "pits" and mounds, as of an extensive series of old disused quarries, received confirmation. I cannot hazard a conjecture as to the extent to which quernstones may have been obtained from the "Cole's Pits"; but it seemed to me extremely likcly that the range of hills in question, here so many hills on sandy formations (our Bagshot Sands, for example) owed its existence, quâ hills, to the protection of the hard "paw" which is so frequently met with in such formations, which I have attempted to account for in the Proceedings of the Geological Association (vol. viii. No. 3), and which was certainly largely worked in places for rude building construction in very early times, large masses of it being seen still in the old Roman wall which to-day completely encircles the area occupied by the ancient town of Silchester. It is possible, too, that such ironstone may have been rich enough in the metal to serve as ore, when iron "forges" were common in past centuries in the forest districts of the south of England. Further support is given to the view which I venture here to put forward as to the origin of the Cole's Pits, by the fact that lower down the hill, and at a rather lower "horizon," there is a sand-pit open in the side of the hill, in which thin bands of ironstone occur, some of which, to judge from their specific gravity, might certainly have been available as ore, under conditions which obtained in the iron industries of the country a few centuries ago. A. IRVING

Wellington College, October 3

\section{The Flow of Streams}

THE observations made by $\mathrm{Mr}$. Maw on a stream flowing into the Lake of 'Thun are an extremely interesting example of wellknown hydraulic laws. It would be well, however, if he would tell us what was the depth of the water; from the observed phenomena I presume it was small. Mr. Smith's very ingenious mode of practically showing the different strengths of a current from surface to bottom should also be supplemented by an account of the size of the stream operated upon. The situation of the point of greatest velocity varies considerably with the conditions of the river or stream, and is by no means fixed. The observations made on some large rivers, notably those by $\mathrm{Mr}$. Revy on the large rivers of South America, seem to show that the greatest velocity is, in such cases, almost, if not quite, on the surface, and that from that point it diminishes uniformly downwards to the bottom. The ratio between the surface and bottom vclocities is, however, a constantly changing one, and in large rivers varies with the depth of the water. Mr. Revy's observations seem to show that in large rivers, where the influence of the banks is practically inappreciable, the surface velocity varies directly as the depth, whilst the bottom velocity varies as the square of the depth; as the depth increases, the difference between the top and bottom currents diminishes, until at a depth of about 7 I feet they are practically equal. These results are borne out by the observations of Messrs. Humphreys and Abbott on the Mississippi and Mr. Gordon on the Irrawaddy. All observations to be useful, thercfore, should give the size of the river or stream operated on. If Mr. Smith has not secn the diagrams given by Mr. Revy in his "Hydraulics of Great Rivers," I think he would be intcrested in them. GEORGE HIGGIN

\section{Lepidoptera}

I AM at present carrying on some researches here, for which a supply of living caterpillars of such large Lepidoptera as the Death's Head, Goat, or Hawk Moth is necessary. As I have had some difficulty in obtaining these, I should feel exceedingly obliged to any of your reaclers who may find or possess larva of the above or other large species, if they could furnish mo with specimens.

Zoological Laboratory, University College, Gower Street, Inndon, October 4 